\title{
LIG1 wt Allele
}

National Cancer Institute

\section{Source}

National Cancer Institute. LIG1 wt Allele. NCI Thesaurus. Code C91270.

Human LIG1 wild-type allele is located within 19q13.2-q13.3 and is approximately 55 kb in length. This allele, which encodes DNA ligase 1 protein, is involved in DNA replication and repair. Mutations of the gene that decrease the enzymatic activity of the protein product are associated with immunodeficiency and increased sensitivity to DNA-damaging agents. 